\title{
Cantrang: A Dilemma in Policy Implementation (Case in Lampung Bay, Indonesia)
}

\author{
Sieć trałowa: Dylemat we wdrażaniu polityki \\ (przypadek zatoki Lampung w Indonezji)
}

\section{Indra Gumay Febryano*,

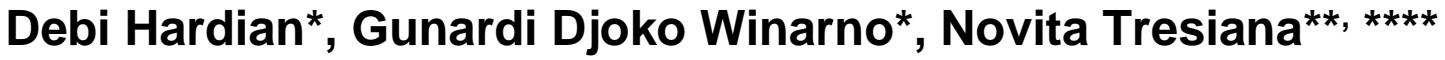

\author{
*Department of Coastal and Marine Zone Management, Postgraduate Program, \\ Universitas Lampung, Bandar Lampung, Indonesia \\ **Department of Public Administration, Faculty of Social and Political Science, \\ Universitas Lampung, Bandar Lampung, Indonesia \\ ***ORCID: 0000-0001-8712-090X \\ ****ORCID: 0000-0001-7242-656X \\ *****E-mail: (Corresponding Author): indragumay@yahoo.com, \\ ORCID: 0000-0001-7242-656X
}

\begin{abstract}
Cantrang is a section of seine nets which has been banned in all regions of Indonesia. However, this policy can stir to pros and cons due to implementation. The purpose of this study is to analyze the success of the stage and the effectiveness of policy implementation on cantrang prohibition in Lampung Bay, Indonesia. Data were collected by interview, observation, and documentation studies, next the policy implementation was reviewed by the marketing policy studies then for further analyze was using ambiguity-conflict matrix. The result of this research shows the unsuccessful of the policy marketing on implementing cantrang prohibition policy from policy acceptance side and policy adoption, also on readiness strategy side is failed. Fisher community do not fulfil the policy and not become a part of it, hesitancy of local government as an executor of the policy, vertical conflict between fisherman and government. The analysis of ambiguity-conflict matrix gives the choice of effectiveness politic model implementation and experimentation, replace the administrative policy implementation. Effective but non-destructive fishing gear can be encouraged to be developed by the government through studies that involving all stakeholders including fisherman and academics. The government is also expected to replace the prohibition policy with a regulatory policy on the cantrang construction and capture area arrangement. In addition, the government is expected to create legal certainty in the field, so it may minimize the fisherman's conflicts and opposition to cantrang prohibition policies.
\end{abstract}

Key words: fishing gear, IUU fishing, Lampung Bay, policy implementation, cantrang

\section{Streszczenie}

Kantrang to sieć trałowa, której użytkowania zakazano we wszystkich regionach Indonezji. Jej wdrażanie ma jednak tak wady, jak i zalety. Celem niniejszej pracy jest analiza sukcesu i skuteczności wdrażania polityki dotyczącej zakazu kantrangu w zatoce Lampung w Indonezji. Dane zebrano na podstawie wywiadów, obserwacji i badań dokumentacji, a następnie wdrożenie polityki zostało przeanalizowane z pozycji polityki marketingowej, po czym do dalszej analizy wykorzystano macierz niejednoznaczności-konfliktu. Wyniki tych badań pokazują, że marketing dotyczący wdrażania polityki zakazu kantrang od strony jej akceptacji i przyjęcia, a także od strony gotowości jej wdrażania, nie powiódł się. Społeczność rybacka nie realizuje polityki i nie staje się jej częścią, samorząd jako wykonawca polityki także zawodzi, następuje wertykalny konflikt między rybakami a rządem. Analiza macierzy niejednoznaczności konfliktu wskazuje na możliwości poprawy skuteczności wdrażania modelu politycznego i 
przygotowania nowej polityki administracyjnej. Rząd może zachęcać do opracowywania skutecznych, ale nieniszczących narzędzi połowowych opracowanych z udziałem wszystkich zainteresowanych stron, w tym rybaków i naukowców. Oczekuje się również, że rząd zastąpi politykę zakazową polityką regulacyjną dotyczącą dopuszczalnych form budowy sieci kantrangu i jej zdolności połowowych. Ponadto oczekuje się, że rząd stworzy skuteczne prawa w tej dziedzinie, dzięki czemu zmniejszeniu ulegnie zakres sprzeciwu wobec polityki zakazu kantrangu.

Słowa kluczowe: sprzęt połowowy, połowy IUU, Zatoka Lampung, wdrażanie polityki, kantrang (sieć trałowa)

\section{Introduction}

One of the most serious threats to sustainable exploitation aquatic resources, the common fisheries policy, and international cooperation to be encouraged better ocean governance is illegal, unreported, and unregulated (IUU) fishing (Falautano et al., 2018). The term of IUU fishing is widely used for: (1) Fishing and activities related to fishing held in contravention of national, regional and international laws, (2) Un-reporting, misreporting or under-reporting information on fishing operations and catch results, (3) Fishing by stateless ships, (4) Fishing in convention areas of Regional Fisheries Management Organizations (RFMOs) by non-party vessels, and (5) Fishing activities which are not regulated by states and cannot be easily monitored and accounted for (FAO 2016).

IUU fishing caused major problems with impacts on social, environment, and economy in all around the world (Petrossian 2015; Young 2016). These can happen because IUU fishing is able to undermine the efforts on sustainability fish resources management and marine biodiversity conservation (Lindley dan Techera 2017; Riskas et al., 2018). Exploitation of fishing resources through IUU fishing is not announced, so it can be extremely underestimated. Overexploitation o fish stocks contrary to the effectiveness of the management measures adopted. In addition, unfair competition arises between fisherman and operators who agree with regulations and those who do not. Furthermore the selling of illegal catches results price fluctuations with an impact on buyers and producers (European Commission 2009; Leroy et al., 2016; Okafor-Yarwood, 2019).

Cantrang is one of the fishing gear which classified as illegal fishing in whole areas of Indonesia. Xue (2003) stated that illegal fishing can cause decay on fish resources and fleet the potency of fisher community economic. According to Bambang (2006) cantrang is a fishing gear with nets shape, it has wings, body and sac, without nets opener. The fishing ground of cantrang is in the area which has muddy substrate or sandy and without coral. Subani dan Barus (1989) stated that cantrang fishing ground is not far from the coast, muddy and sandy substrate, flat bottom surface. Hakim dan Nurhasanah (2016) said fisherman like to use cantrang because it has high productivity and easy to maintain.

Initially, the government introduced cantrang as a substitute of trawl which prohibited through Presidential Decree Number 39 in 1980. Cantrang is considered to be able to disrupt and damage the sustainability of fish resources because it can threaten the extinction of biota when operated, also cantrang can ruin the habitat, and endanger the safety of users (Nababan et al., 2018). This is inseparable from the character of cantrang which actively operationalized (BPPI, 1999). Eventually, Indonesia government prohibit the cantrang utilization which a part of cantrang on all lanes of fishing in whole Indonesia areas. Cantrang restriction is appointed on Minister of Marine Affairs and Fisheries Regulation of Republic Indonesia Number 71/Permen-Kp/2016 as regards on fishing tracks and placement the fishing gears in management fishery territory of Republic Indonesia. This policy is strongly associated with the presence of cantrang which part of IUU fishing. Both of these policies became a base and parameter for policy implementation on cantrang prohibition. Unfortunately, the enforcement of this policy is not followed by study impact and universalization happened in implementation, including strategies that must be carried out by government. As a result, prohibition policy on cantrang bring rough reaction from fisher community, also it leads vertical conflict between fisherman and government.

Lots of research reveals that cantrang prohibition can impact unemployment, welfare reduction, and crime (Pahlevi and Hidayat, 2017; Sari and Brata, 2017; Suprapti et al., 2017; Suwarsih 2013). Besides, other studies state these prohibition caused down lift on catch result about 23,5\%-30\% (Muntalim and Choiruddin, 2016; Sukandar et al., 2015). Nevertheless, the research which utters on how the utilization of marketing policy to see the success stages and effectiveness for implementation on prohibition cantrang policy is still rare. The aim of the study is to analyze the success of the stage and effectiveness of policy implementation on cantrang prohibition in Lampung Bay, Indonesia. The resulting policy recommendations may be useful for stakeholder to embody the responsibility, optimal, and sustainability of fish resources utilization, also decrease the conflict use.

\section{Methods}

The study was conducted in Port of Fisheries Lempasing, Bandar Lampung City on July-September 2019. Data were collected by interview, observation, and documentation studies. There were 23 people interviewed consist of: civil servant of Ministry of Marine Affairs and Fisheries (Kementerian Kelautan dan Perikanan Republik Indonesia/KKP) Republic 
of Indonesia (2 persons), civil servant of Marine and Fisheries Office (Dinas Kelautan dan Perikanan/DKP) of Lampung Province (5 persons), universities (3 persons), ship owners (5 persons), ship caretaker (6 persons), skipper (2 persons). Collected data were analyzed for policy implementation on cantrang prohibition through marketing policy analysis (Nugroho, 2015) and ambiguity-conflict matrix (Matland, 1995).

Marketing policy analysis can explain the extent of the successful policy prohibition implementation which seen from the three processes that influence each other, namely:

a. Policy acceptance, when the fisher community can understand the cantrang prohibition policy as a rule to actualize the responsibility, optimal, and sustainable utilization of fish resources. On the other hand, the local government in this context also understands the policy as the duty which must be carried out.

b. Policy adoption, when the fisher community received the prohibition on cantrang policy as a rule which required; while the government accepts the policy as task that must be implemented; and

c. Strategy readiness, when the fisher community enforce and becomes a part of the cantrang prohibition policy; On the other side, the local government ready to become a policy executor.

The ambiguity-conflict matrix developed by Matland (1995) is used to further analysis to find the effectiveness of policy implementation (Figure 1). This model divides the effectiveness of policy implementation into four parts, that are: (1) Administrative implementation is a suitable implementation for daily operations of government bureaucracy, this policy has low ambiguity and conflict; (2) Political implementation is the implementation which needs to be politically carried out, because even the ambiguity is low, the level of conflict is high; (3) Experimental ambiguity applied on ambiguous policy but the level of conflict is low; (4) Symbolic implementation is carried out on policy that has high ambiguity and high conflict.

\section{Conflict}

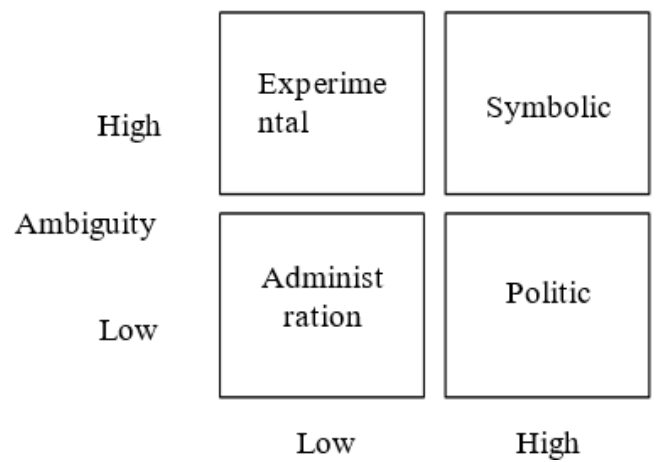

Figure 1. Ambiguity-Conflict Model, source: Matland (1995)

Result and discussion

\section{General Condition of Location}

Lampung Bay is one of the bays which located in the southern tip of Lampung Province, included an administrative area in Bandar Lampung City, South Lampung Regency, and Pesawaran Regency. As a coastal area, Lampung Bay has diverse activities that include settlements and urban areas, agriculture, forestry and plantation, manufacturing industry, fisheries utilization and aquaculture, water transportation, military, and tourism. Spacious waters area reaches 161,178 ha (Table 1 ) were inhabited by various species of fish, both demersal and pelagic.

Table 1. Large Area of Lampung Bay Coastal, source: (Damai, 2012)

\begin{tabular}{|l|c|c|c|}
\hline No. & $\begin{array}{c}\text { Ocean depth } \\
(\mathrm{m})\end{array}$ & $\begin{array}{c}\text { Waters area } \\
\text { (ha) }\end{array}$ & $\begin{array}{c}\text { Percentage } \\
(\%)\end{array}$ \\
\hline 1. & $0-20$ & 37,797 & 23.45 \\
\hline 2. & $20-25$ & 48,172 & 29.89 \\
\hline 3. & $25-30$ & 32,432 & 20.12 \\
\hline 4. & $30-50$ & 40,290 & 25.00 \\
\hline 5. & $50-80$ & 2,369 & 1.47 \\
\hline 6. & $>80$ & 119 & 0.07 \\
\hline \multicolumn{2}{|c|}{ Total } & 161,178 & 100.00 \\
\hline
\end{tabular}

According to the results of the Research Center for Oceanographic Research and Development (2000) in the Department of Fisheries and Maritime Affairs of Lampung Province (2007) showed that from five observation sites in Lampung Bay, there were about 7,072 individuals from 31 tribes and 162 fish species, 40 species were target fish (food). The major fish category consists of 22 tribes with 160 species. The target fish divides into 9 tribes and 10 species, while the indicator fish consists of 1 tribe with the 16 highest abundance species on the west of Pahawang Island it is about 1,556 individuals. Based on fish category, the highest abundance of major fish was found on the west of Pahawang Island, while the highest target fish abundance was found on the west of Tegal Island, and the highest indicator fish abundance about 31 individuals were found on the east of Pahawang Island. The substantial number of major fish species can be found on the east side of Legundi Island, while the highest target fish and indicator species come from Sebuku Island on the west side The fishing fleet that operates in Lampung Bay is about 2,500 units, with various types and sizes of ships, both moto-driven and not motor-driven. The small motorized ships type ( $<5$ tons and 5-10 tons) is mostly operated by fisherman because the Lampung Bay fisherman are dominated by smallscale fisherman (artisanal), which generally one-day fishing (Damai 2012). The ship's size with cantrang that operating along the Lampung Bay about 15- 30 G T, 29 units in 2019. Cantrang is usually manned by a skipper and the Head of the Machine Room (KKM), with the number of Ship Men (ABK) ranging from 10-15 people each ship. Marketing Policy Cantrang Prohibition 
Marketing policy is a standard process after the formulation of a policy (Nugroho, 2015). The successful implementation of cantrang prohibition policy can be seen from three processes in marketing policy, that are: policy acceptance, policy adoption, and strategic readiness. Based on those processes, there is a failure on the stage of policy acceptance and policy adoption, both from the fisherman and local government as policy executor. According to Digal dan Placencia (2017) showed the uplift of the fisherman awareness on sustainable fishing is an ideal matter and has implications on fisherman's decision to practice sustainable fishing.

Failure overview on policy acceptance and policy adoption of cantrang prohibition from the target version (fisher) show the disobedient on policies as an output of implementation. The operation of ships with cantrang is still many, although some ships are caught. If one ship is captured, all ships in the middle of the sea are called home and berth at the port until the patrol ends. Fisherman are not wary and still go sailing, even though they might be caught by patrols from authorities. The reason is that they have to get money to support their families life, but they only able to operate cantrang. According to Anna et al. (2019); Das et al. (2015) that fisherman families life have very limited access to education, health, housing, and others.

The amount of cantrang decreased after the Minister of Marine and Fisheries Regulation of Republic Indonesia Number 71/Permen-Kp/2016 published and several ships have caught. The number of ships dropped from 38 to 29 ships. Cantrang prohibition can affect the economic loss for fisherman, the disadvantages are:

a. Reduction on Fish Production

The amount of fish catch production decreased because of the presence of several inoperative ships. The average of cantrang productivity about 10 tons/ship/trip. Generally, cantrang ships go to sea 3 times every 2 months, so that it can reach 18 times a year. Therefore, cantrang productivity is 180 tons/ship/year. There are 29 ships operate in Lampung Bay, it can produce 5,220 tons/year. Fish catch production from cantrang has not been recorded since 2016 at the fish auction place of the Lempasing Port, because the KKP excluded cantrang from recording fishing statistics. As a result, there is no income from regional revenue due to catches production from cantrang ships are not sold through auction, but directly sold from ships when berthing at Lempasing Fishery Port and in the middle of the sea (sold as grouper feed that is cultivated in floating net cages).

b. Deflation on fisherman revenue

The fall of cantrang ships number which operates disrupt the fisherman economy. The average revenue from catch produce with cantrang is about $35 \%$ operating costs, $37 \%$ for ship owners, $38 \%$ for caretakers, skipper, KKM, and ABK. The ABK earns 5 million rupiah/month with living cost about 3,5 million rupiah/month. If the ships are not in operation, the income of $\mathrm{ABK}$ will be lost and living cost will be covered by the debt that will be paid at the time of return back to sea. When the patrols come, cantrang ships will back immediately to the port, even though some of them only left for a day and have not brought the result. They leaned on the port for more than a week until the patrol finished. As long as they do not go to sea, the lives of fisherman, especially the caretaker, skipper, KKM and ABK, rely on debts from ship owners and food stalls around the port.

c. The domino effect on related business

The decline on catch result productivity by cantrang also affects other businesses that use fish crap, which is small and does not have economic value, such as pepetek (Leiognathus spp), tanjan (Clupea spp), kurisi (Nemipterus spp), because the price is affordable. Cultivator whose use floating net cages use the crap fishes for feeding kerapu macan (Epinephelus fuscoguttatus) and kerapu bebek (Cromileptes altivelis). Besides floating net cages, crap fishes also used as a raw material for fish fillet products called surimi. Surimi is a material for fish balls, fish chips, traditional food (otak-otak and somai) and other value-added products from the utilization of small fish or other uneconomic fish. The waste fillet from surimi is usually used also for small crab baits by trap. Production results of cantrang also have economically multiplier effect on seller/supplier logistics, ABK consumption, grocer and other.

The image of failure on policy acceptance and policy adoption from the local government (DKP) version as policy executor (bureaucrats on the street) is seen more clearly weak supervision, because patrols are conducted not in every day or periodically. This condition can be an opportunity for cantrang fisherman to go back to sea. Officers do not pay attention to cantrang ships that go to sea unless patrol assignments. Generally, cantrang ship is caught by patrols from KKP, while for supervisors in region tend to make silent decisions until the government step in. Indecision from government on implementing cantrang prohibition policy leads to an omission in field. Sander et al. (2014) argue that illegal fishing is not only a matter of regulation and economy but also a problem that needs investment in the application of law and order which efficient and effective. Also from Liao et al. (2019) which expressed the efforts to strengthening the rule of law and review the regulations and policies in tackling these problems. 
An important substance of the success in policy acceptance and policy adoption is the precisely prohibition policy model that used for the resolution of economic and social problems as a result of the policy. It is strongly associated with the lack of socialization on cantrang prohibition due to the lack of charge. Fisherman admit that not all of them received information about cantrang prohibition regulations. Some claimed that they did not understand the purpose, even though they got the information. The most crucial thing from this socialization is the different view in understanding and perception between the fisher community and the local government. The perception of fisherman and the local government seems to be inharmonic in understanding and accepting the policy. Based on fisherman views, cantrang can be economically profitable, it is considered to be safe for environment and fish resources. On the other hand Government argues cantrang may endanger the sustainability of fishery resources and damage the aquatic environment. This also supported by Hardian et al. (2019) which informs the in harmony perceptions between fisherman and government can cause the failure of the cantrang prohibition policy in Lampung Bay.

According to fisherman from the fishing ground (capture area), Lampung bay at range 4- 12 miles is a deep-sea with not overly rocky. If the location of fishing ground is in the reef areas, the nets of cantrang may be stuck on the reef. Other fisherman say that size of cantrang mesh is plenty big which about over 1 inch, this makes the production catch more selective because small fishes are not able to catch. There are two opinions from government and academics. Cantrang is degradative for environment and fish resources, while others argue the opposite. Research from Sukandar et al. (2015) showed cantrang activities can cause degradation on habitat and fish resource because the operations carried out by pull out the nets from the bottom of the water which can cause a significant impact on underwater ecosystems.

According to Nababan et al. (2018), there is an assumption that cantrang and bottom cantrang are the same (even though they are different), so both of them are included in prohibited fishing gear based on the Minister of Maritime and Fishery Regulation of Republic Indonesia Number 71/Permen-Kp/2016. The obscurity opinions about the cantrang principle same as bottom cantrang are the impact of weak comprehensive study of the cantrang prohibition. The failure of the state in maintaining marine ecosystems cannot be attributed to fisherman who merely adapt to the quality of the waters dropped. The policy on cantrang prohibition such the arrogance of the state which covers its weaknesses, but they places the restoration costs on fisherman who incidentally have been protecting the waters, supporting their lives and the community's economy and also developing applied technology which is considered effective.

Policy acceptance and policy adoption become crucial points for the next process as well as two inherent things. The failure of the policy acceptance and policy adoption process shows futility on readiness strategy. It occurs when fisher communities do not undertake and not being a part of the cantrang prohibition policy. Local government (province and district) governments are half-heartedly in implementing policies; only the central government (KKP) is ready to carry out the policy. As a result, the cantrang prohibition policy leads to vertical conflicts between fisherman and government. All fisherman include the shipowner/coach, caretaker, skipper, KKM and ABK reject the Minister of Maritime and Fishery Regulation of Republic Indonesia Number 71/Permen-Kp/2016. Even though it has already entered two years from the time of transition given by the government (end of 2017), fisherman keep operating the cantrang until the end of the research (end of July 2019). They assume that the transition deadline on fishing gear is too short. Alteration in fishing gear is a complicated problem because fisherman owe money to banks or investors to build the ships and purchase cantrang. Fisherman debt that not paid off, and they are still burdened with new debts to purchase the operational for fishing gear. Although there is support from the government, the target more intended to fisherman who have ships with size below $10 \mathrm{GT}$, while generally the size of the cantrang ships above $10 \mathrm{GT}$.

Besides the period of policy implementation on cantrang prohibition is too short and also the problem of debt, fisherman assess the government does not consider the justice factor in the application. One of the main reasons for the fisherman rejection is triggered by injustice in the enforcement of policy. There is distinction in location or target policies. In other areas such as Central Java and East Java, the application of cantrang fishing gear is still permitted by the government. This condition is inseparable from the policy on cantrang prohibition which is very fraught with political content. There is a strong political intervention in cantrang prohibition regulation. The amount of cantrang in Central Java and East Java Provinces is about 5,000 ships, while cantrang that owned and operated by fisherman in Lampung Bay only 29 ships. It seems unfair because the area of cantrang fishing ground from both provinces is not only limited to the northern shores of Java but also reach East Lampung up to Borneo. Differentiations on policy lead fisherman to commit mass demonstrations to revoke the policy. In addition, fisherman also claim legal protection for a set of seized ships which ranges from more than 50 million rupiah and it depends on the number and size of fishing gear confiscated. The fisherman requested that the captured fishing gear which confiscated can be returned, although this condition actually does not guarantee that 
the cantrang fishing gear would not be operated anymore.

\section{Ambiguity-Conflict Implementation on Cantrang Prohibition Policy}

The choice of implementing a cantrang prohibition policy is an administrative model based on an ambiguity-conflict matrix developed by Matland (1995). Cantrang prohibition policy is a part of daily operation government bureaucracy if it seen from administrative model. It is because of central government assuming the purpose of the policy easy to understand (low ambiguity). Fisherman become a target of the policy and local government as the executor will receive and carry out the policy without conflict (low conflict). Administrative model use two strategies, that are: (1) top-bottomer policy implementation like mobilization and taking space with the fisherman and (2) command and control implementation like monopoly over government forced mechanisms through control and supervision, penalty for rejection or violation (zero minus models). Hill dan Hupe (2006) showed how the model implementation indicates the tendency of top-down and forced model modification which increasingly shifted to bottomup model as democracy develops. According to Arceo et al. (2013), to create top-down in fishery implementing towards participative manage order and effective convergent, it needs policy reformation and major national institutional, social arrangement, and organization reinforcement which required time and resources.

The description of comprehension (ambiguity) on policy and importance (conflict) of the implementation choice about cantrang prohibition can be explained as follows:

a. For the central government (KKP), the prohibition policy is already suitable with necessity and strategic plans in Indonesia. The most critical issue for fisheries in Indonesia is the overfishing and overexploitation which can endanger the sustainability of national fisheries in the future. The practice of infraction in the form of the prohibition operation of fishing gear, fishing activities with no permission, unreported fishing catches, and the infringement of applicable laws and regulations, all matters included in Illegal, Unreported, Unregulated (IUU) Fishing. This activity can damage fish resources, ecosystems and environment, also it may inhibit the export of fishery products.

b. For the local government (DKP), the dilemma and conflict over the cantrang prohibition policy affect the conflictual relations. This becomes an issue and dilemma because local fisherman protests on office, while the efforts on collecting data on ships and fishing gear cannot be optimal due to poor data, unappropriate object and rejection from local fisherman. Fisherman assume that the cantrang prohibition policy is not prepared to be fully carried out, because the transition times for fishing gear takes a long time. Fisherman are also worried and they refuse to replace cantrang.

c. For cantrang fisherman, they assume government do not have an empirical-based argument about the destructive that caused by cantrang, because cantrang had been operated for a long time before trawling was known, also it's the location of cantrang fishing ground is in the middle and above 50 miles which would not damage coral reefs. The prohibition policy may totally shut off the business of cantrang fisheries. According to fisherman, there are some historical facts that unknown to government and the existence of cantrang ships are not recognized, that are: (1) Cantrang application is a custom that has become a tradition and obligation to conserve; (2) fisherman have been buying and developing fishing ship technology by themselves and also they innovating self-taught fishing without government direction; last (3) fisherman develop talents and skills independently and self-taught based on their experience and years of experiments.

Conflicts that come up from the implementation of cantrang prohibition policies can be illustrated by the typology of fisheries conflicts based on Charles (2001) such as (1) fisheries jurisdiction, this conflicts usually happen on the government roles issues, territorial borders, shipping access, and other policy planning functions (this conflict usually occurs at the policy and planning level); (2) management mechanism, this conflict occurs at the management level about program for the short-term fisheries implementation, catch conflicts, fishing license or fisheries law enforcement; (3) internal allocations, conflicts which go on the operational level between fishery persons about fishing permits, fishing gear conflicts, problems between fisherman and entrepreneurs, or other actors; and (4) external allocation, this operational level conflict is the conflict between domestic fisherman and fisherman from other countries, other sectors and the public.

Initially, the conflict on the cantrang prohibition at the internal allocation (low conflict) concerns about supervision and spatial arrangement, also fishing gear management. Then the conflict turned into a management mechanism issues (high conflict) which put the government (KKP) as the subject of problems who have to deal with the fisherman. Cantrang which banned by the government may lead to illegal fishing. Bacalso et al. (2016); Nahuelhual et al. (2018); Mirrasooli et al. (2019); Mullie et al. (2019); Rodriguez-Garcia et al. (2019) states the effects of illegal fishing are bio-physical effects, socioeconomic drivers and consequences at once.

In fact, the policy of cantrang prohibition based on the government's concern to resolve marine degrada- 
tion that caused by excessive and inadvisable extraction from the past, so some territorial waters have been over-exploited and destroyed the habitat. The government tend to use the conservation paradigm which extremely caused high-level conflict by emphasizing the importance of the fish stocks sustainability in long term, avoid market rationalization, government perceived fisherman to pursue their own interests, so the control and limitation on fisherman are necessary. Research conducted by Bladon et al. (2018); Davies et al. (2015) provided how the effective policy implementation for management interventions often limited by uncertainty, especially in small scale fisheries and developing countries.

The complexity of marine and fish resources can be described as an arena of competition between conservation, rationalization, and social/community paradigms (Charles, 2001). The contradiction between production and resource degradation, also less participation from local government and fisherman on undertaking cantrang prohibition policy, can cause the vertical conflicts between fisherman and government. When this conflict more incisive, the government adopted a policy by holding a temporary cantrang prohibition on 2016-2017. This is based on the government's desires and strategies in strategic readiness and minimizing conflict. Murshed-e-Jahan (2014) explains that conflicts between fisheries stakeholders happened because of distinction in power, interests, values, priorities, and ways of resource exploitation.

The delay policy gets chosen because of illegal fishing which often found in Lampung Bay, such as:

a. There are still many cantrang ships that operate without SIUP (Fisheries Business License), SIPI (Fishing License), SLO (Decent Operation License) and SPB (Sailing Approval Licence). Lots of cantrang ships operate without permission, there they are allowed to go to sea in Central and East Java through the Minister of Maritime and Fisheries Letter No. 18 / Men-KP / 2018 dated January 12, 2018, about the Provision of Discretion Extension on the transition period of cantrang prohibition to Central Java Regional Government, while in Lampung Province it is prohibited. The cantrang prohibition in Lampung Province leads social jealousy among cantrang fisherman. Every time they go to sea, they do not report to local officials. This could be harmful if there is an accident in the middle of the sea because it is not easy to detect data on sailing ships. After the issuance of Permen KP No. 71 on 2016, the Lampung Province Maritime and Fisheries Office no longer publish SIUP, SIPI, SLO and SPB for cantrang ships.

b. There is a mark-down practice in the ships permission arrangement, where the size (Gross Tonnage) is dropped so that permit processing can be done in the Province, but not in the central/ KKP. The permission arrangement for vessels over 30
GT is under the authority of the KKP. Obtaining permits to the KKP needs a huge expense and takes a long time. The practice of markdown is data manipulation which includes activities that disobey the law both for those who request and publish the letters. Markdown practices can cause loss in state by the side of PNBP, subsidies and depletion of fish resources. To anticipate this condition, there should be a reiterant data collection and measurements that are recently starting to be carried out by the Department of Maritime and Fisheries of Lampung Province with the Ministry of Transportation.

c. Lack of reporting. Post-Permen KP No. 71 of 2016 published, fish catches from cantrang fishing gear were not reported to the Lempasing Fishery Port and were not auctioned at the local fish auction.

The postponement policy which coupled with environmentally friendly gill net (millennium nets) socialization and it provides support ships with sizes below 10 gross tonnages (GT) to fisherman. This would become the initial strategy which gets a forced for compliance by post-delay policies However, the implementation of fishing gear replacement is still ineffective and unproductive, because it takes a longer time and more difficult to operate, the price of the net is more expensive, the maintenance of the net is more complicated and often stuck or loss and the production results are not as economical as cantrang. In addition, fishing gear replacement does not match with the number of effective fishing (according to fisherman, the effective fishing is above 60 pieces, while the support provided only below 60 pieces). For example, fisherman who get of 35 pieces must increase their nets to 60 pieces so that the catches result may be economical. This uplifted requires additional costs for fisherman. The cost of 1 piece of the cheapest millenium nets are about 3 million rupiah, so they must raise the costs about 75 million rupiah. On the other hand, generally fisherman able to buy cantrang nets for 15-20 million rupiah (much cheaper) with higher productivity levels. Five respondents (shipowner) has been trying to replace fishing gear, but they failed and got debt from the bank because the result is different from cantrang. DKP and fisherman assumed that cantrang prohibition policy is not well prepared to execute because of the low acceptance and high potency of social restless. Top-down and forced administration model without stakeholder consultation and suitable implementation on local level lead the opposition to local government. Procrastination implementation indicates government unprepared execution, so scientific observations by expertise from universities in fisheries major are necessary, also persuade fisherman as a partner in empirical study on replacement cantrang operationalization. Bull et al. (2014), states 
that conversation intervention or effective management must have measurable benefits, thus it requires appropriate framework references to evaluated.

The dilemma in implementing cantrang prohibition can be seen by procrastination policies strategy. This requires suitable model substitution which useful to stakeholders in creating responsible, optimal, and sustain utilization on fish resources According to Ben-Haim et al. (2013), many decisions of policies need choice among several choices which one of them has good result although it is uncertain. Uncertain innovation comes from a good option. Policymakers makers face an innovation dilemma when choosing between convincing option but more certain and other option which less convincing but more familiar.

The selection of implementing model administration needs to correct by suitable and smart choices. This implementation should be concern on change of the fisherman condition and get the concept also submission from fisherman or local government (DKP). According to Martland (1985) analysis, the implementation of cantrang prohibition policy will be success if using the option of political combination and experimental model. The combination from both models become a selection because of the difference in interests lead low conflict (internal allocation) to high vertical conflict (management mechanism). KKP and DKP become subjects of issues that must face the cantrang fisherman. The diverse perception among stakeholders on cantrang prohibition specific policy with high-risk level (if failed) can be implemented with experimental model (pilot project). Trials that took a year on fishing gear replacement are expected to overcome this dilemma policy.

The political model is required to manage the conflict parties to the realized the equality and reserve the right on argumentation. The expected result is the formation of collaborative management in managing the living space of fisheries communities, without contradiction the waters conservation and rehabilitation mission which developed by the government. It is supported by the opinion of Msomphora (2016) about the importance of the relationship between stakeholders, such as between the government (as a facilitator and regulator) and users who have an interest in resources. Nielsen et al. (2015) stated that stakeholder participation in making fisheries management decision is a key to good governance which starting from the management plan concept to its implementation.

\section{Conclusion}

The implementation of the cantrang prohibition policy failed in terms of marketing policy. This failure can be seen from policy acceptance, policy adoption, and readiness strategies. Vertical conflict comes up between fisherman and the government, when fishing communities do not carry out and not a part of the policy, while the local government is unsure to execute the policy. Administrative models of implementing cantrang prohibition policies based on ambiguity-conflict matrix can be more effective if using a choice of political and experimental models. The central government (KKP) is pushed to develop effective and eco-friendly fishing gear through studies involving all stakeholders including fisherman and academics. In addition, the prohibition policy can be changed to a regulatory policy on the construction of cantrang fishing gear and fishing ground management. The government is also expected to be able to create legal certainty in the field considering that fishing, confiscating the fishing gear, and blackmailing the fisherman are actually contra-productive to fisherman's welfare, even it may increase the conflict and opposition to the cantrang prohibition policy.

\section{Acknowledgement}

The author would like to express the gratitude and appreciation to the Research and Community Service Institute of Universitas Lampung for their financial support through DIPA BLU in 2019. Also thankful and tribute for Head of the Port of Fisheries Lempasing Beach Bandar Lampung with all parties whose have facilitated this research.

\section{References}

1. ANNA Z., YUSUF A.A., ALISJAHBANA A.S., GHINA A.A., RAHMA, 2019, Are Fisherman Happier? Evidence from A Large-Scale Subjective Well-Being Survey in A Lower-Middle-Income Country, in: Marine Policy, 106, p. 103559.

2. ARCEO H.O., CAZALET B., ALINO P.M., MANGIALAJO L., FRANCOUR P., 2013, Moving Beyond A Top-Down Fisheries Management Approach in The Northwestern Mediterranean: Some Lessons from The Philippines., in: Marine Policy, 39, p. 2942.

3. BACALSO R.T.M., WOLFF M., ROSALES R.M., ARMADA N.B., 2016, Effort Reallocation of Illegal Fishing Operations: A Profitable Scenario for The Municipal Fisheries of Danajon Bank, Central Philippines, in: Ecological Modelling, 331, p. 5-16.

4. BAMBANG N., 2006, Petunjuk Pembuatan dan Pengoperasian Cantrang dan Rawai Dasar Pantai Utara Jawa Tengah [Instruction on Making and Operating Cantrang and Bottom Longline in North Coast of Central Java], Balai Besar Pengembangan Penangkapan Ikan, Semarang (in Indonesian).

5. BEN-HAIM Y., OSTEEN C.D., MOFFITT L.J., 2013, Policy Dilemma of Innovation: An Info-Gap Approach, in: Ecological Economics, 85, p. 130-138.

6. BLADON A.J., MOHAMMED E.Y., ALI L., MILNER-GULLAND E.J., 2018, Developing A Frame of Reference for Fisheries Management and Conservation Interventions, in: Fisheries Research, 208, p. 296-308.

7. BPPI [Balai Pengembangan Penangkapan Ikan], 1999, Kumpulan Paket Teknologi [Collection of 
Technology Packages], Balai Pengembangan Penangkapan Ikan, Semarang (in Indonesian).

8. BULL J.W., GORDON A., LAW E.A., SUTTLE K.B., MILNER-GULLAND E.J., 2014, Importance of Baseline Specification in Evaluating Conservation Interventions and Achieving No Net Loss of Biodiversity, in: Conservation Biology, 28, p. 799-809.

9. CHARLES A., 2001, Sustainable Fishery System, Blackwell Science Ltd, Oxford.

10. DAMAI A.A., 2012, Sistem Perencanaan Tata Ruang Wilayah Pesisir: Studi Kasus Teluk Lampung [Spatial Planning System on Coastal Area], Dissertation, Sekolah Pasca Sarjana Institut Pertanian Bogor, Bogor. (in Indonesian).

11. DAS M.R., RAY S., KUMMAR U., BEGUM S., TARAFDAR S.R., 2015, Livelihood Assessment of The Fisherman Community in The South West Region of Bangladesh, in: Journal of Experimental Biology and Agricultural Sciences, 3(4), p. 353-361.

12. DAVIES T., MEES C., MILNER-GULLAND E.J., 2015, Second-Guessing Uncertainty: Scenario Planning for Management of The Indian Ocean Tuna Purse Seine Fishery, in: Marine Policy, 62, p. 169177.

13. DIGAL L.N., PLACENCIA S.G.P., 2017, Factors Affecting The Adoption of Sustainable Tuna Fishing Practices: The Case of Municipal Fishers in Maasim, Sarangani Province, Region 12, Philippines, in: Marine Policy, 77, p. 30-36.

14. DINAS PERIKANAN DAN KELAUTAN PROVINSI LAMPUNG, 2007, Pemetaan Terumbu Karang di Teluk Lampung [Coral Reefs Mapping in Lampung Bay]. Dinas Perikanan dan Kelautan Provinsi Lampung, Bandar Lampung. (in Indonesian).

15. DINAS PERIKANAN DAN KELAUTAN PROVINSI LAMPUNG, 2018, Statistik Perikanan [Statistics of Fisheries], Dinas Perikanan dan Kelautan Provinsi Lampung, Bandar Lampung (in Indonesian).

16. FAO (Food and Agriculture Organization), 2016, Illegal, Unreported, and Unregulated Fishing, http://www.fao.org/3/a-i6069e.pdf (18.9. 2019).

17. FALAUTANO M., CASTRIOTA L., CILLARI T., VIVONA P., FINOIA M.G., ANDALORO F., 2018, Characterization of Artisanal Fishery in A Coastal Area of The Strait of Sicily (Mediterranean Sea): Evaluation of Legal and IUU Fishing, in: Ocean and Coastal Management, 151, p. 77-91.

18. HAKIM L., NURHASANAH., 2016, Cantrang: Masalah dan Solusinya [Cantrang: Problems and Solutions], in: Prosiding Seminar Nasional Riset Inovatif(Senari) ke-4 Tahun 2016, p. 216-225. (in Indonesian).

19. HARDIAN D., SUPONO, FEBRYANO I.G., DAMAI A.A., WIDIASTUTI L.L., 2019, Perception of Fisherman and Government on Implementation of The Cantrang Fishing Ban in Lampung Bay. Proceeding The International Conference on Marine Sciences and Coastal Engineering and Sciences 2019.

20. HILL M., HUPE P., 2006, Implementing Public Policy, Sage, London.

21. LEROY A., GALLETTI F., CHABOUD C., 2016, The EU Restrictive Trade Measures Against IUU Fishing, in: Marine Policy, 64, p. 82-90.

22. LIAO C-P., HUANG H-W., LU H-J., 2019, Fisherman's Perceptions of Coastal Fisheries
Management Regulations: Key Factors to Rebuilding Coastal Fishery Resources in Taiwan, in: Ocean and Coastal Management, 172, p. 1-13.

23. LINDLEY J., TECHERA E.J., 2017, Overcoming Complexity in Illegal, Unregulated and Unreported Fishing to Achieve Effective Regulatory Pluralism, in: Marine Policy, 81, p. 71-79.

24. MATLAND R.E., 1995, Synthesizing The Implementation Literature: The Ambiguity-Conflict Model of Policy Implementation, in: Journal of Public Administration Research and Theory, 5(2), p. 145-174.

25. MIRRASOOLI E., GHORBANI R., GORGIN S., AGHILINEJHAD S.M., JALALI A., 2019, Factors Associated with Illegal Fishing and Fisher Attitudes Toward Sturgeon Conservation in The Southern Caspian Sea, in: Marine Policy, 100, p. 107-115.

26. MULLIE W.C., 2019, Apparent Reduction of Illegal Trawler Fishing Effort in Ghana's Inshore Exclusive Zone 2012-2018 as Revealed by Publicly Available AIS Data, in: Marine Policy, 108, p. 103623.

27. MUNTALIM, CHOIRUDDIN M.S., 2016, Pengaruh Kebijakan Penggunaan Alat Tangkap Pukat Tarik (Seine Nets) terhadap Pendapatan Nelayan di Kabupaten Lamongan [The Influence of Trawl Fishing Gear (Seine Nets) Utilization of Fisherman Income in Lamongan Regency], in: Jurnal Grouper, 7(1), p. 20-24 (in Indonesian).

28. MURSHED-E-JAHAN K., BELTON B., VISWANATHAN K.K., 2014, Communication Strategies for Managing Coastal Fisheries Conflicts in Bangladesh, in: Ocean \& Coastal Management, 92, p. 65-73.

29. MSOMPHORA M.R., 2016, Conflict Resolution and The Delegation of Authority In Fisheries Management: The Case of Outer Hebrides Inshore Fisheries Group in Scotland, in: Marine Policy, 73, p. 263-275.

30. NABABAN B.O., SOLIHIN A., CHRISTIAN Y., 2018, Dampak Sosial Ekonomi Kebijakan Larangan Pukat Hela dan Pukat Tarik di Pantai Utara Jawa [Socio-Economic Impact of Pukat Hela and Pukat Tarik Prohibition in North Coast of Java], https:// www.conservation-strategy.org/sites/default/files/fie ldfile/MFP_Trawl_Ban_Java_Bahasa_Optimized.pd f (18.09. 2019) (in Indonesian).

31. NAHUELHUAL L., SAAVEDRA G., BLANCO G., WESSELINK E., CAMPOS G., VERGARA X., 2018, On Super Fishers and Black Capture: Images of Illegal Fishing in Artisanal Fisheries of Southern Chile, in: Marine Policy, 95, p. 36-45.

32. NIELSEN K.N., HOLM P., ASCHAN M., 2015, Results based Management in Fisheries: Delegating Responsibility to Resource Users, in: Marine Policy, 51, p. 442-451.

33. NUGROHO R., 1995, Public Policy, Elex Media Komputindo, Jakarta.

34. OKAFOR-YARWOOD I., 2019, Illegal, Unreported and Unregulated Fishing, and The Complexities of The Sustainable Development Goals (Sdgs) for Countries in the Gulf of Guinea, in: Marine Policy, 99, p. 414-422.

35. PAHLEVI M.F.R., HIDAYAT Z., 2017, Implementasi Kebijakan Pelarangan Alat Tangkap Cantrang di Kabupaten Rembang [The Implementation on Cantrang Prohibition Policy in Rembang Regency], in: Journal of Public Policy and Management Review, 6(2), p. 200-214 (in Indonesian). 
36. PETROSSIAN G.A., 2015, Preventing Illegal, Unreported and Unregulated (IUU) Fishing: A Situational Approach, in: Biological Conservation, 189, p. 39-48.

37. RISKAS K.A., TOBIN R.C., FUENTES M.M.P.B., HAMANN M., 2018, Evaluating The Threat of IUU Fishing to Sea Turtles in The Indian Ocean and Southeast Asia Using Expert Elicitation, in: Biological Conservation, 217, p. 232-239.

38. RODRIGUEZ-GARCIA O.U., SEIJO J.C., DE ANDA-MONTANEZ J.A., 2019, Recovery Timelines of Vulnerable High Value Species Under Moratoria: Dealing with Uncertain Levels of Illegal Fishing, in: Fisheries Research, 220, p. 105345.

39. SANDER K., LEE J., HICKEY V., MOSOTI V.B., VIRDIN J., MAGRATH W.B., 2014, Conceptualizing Maritime Environmental and Natural Resources Law Enforcement - The Case of Illegal Fishing, in: Environmental Development, 11, p. 112122.

40. SARI HR, BRATA NT., 2017, Studi etnoekologi tentang nelayan dan jaring cantrang di Kabupaten Rembang [Ethnoecological study of fisherman and cantrang nets in Rembang Regency], in: Jurnal Sosiologi Walisongo, 1(2), p. 135-146 (in Indonesian).

41. SUBANI W., BARUS H.R., 1989, Alat Penangkapan Ikan dan Udang Laut di Indonesia [Fishing and catching shrimp gear in Indonesia], Balai Penelitian dan Pengembangan Pertanian, Jakarta (in Indonesian).

42. SUKANDAR, RAKA D.G., SETYOHADI D., SAMBAH A.B., BINTORO G., DARMAWAN, IKA L., FUAD., 2015, Tinjauan Akademis terhadap Permen KP No.2/Permen-KP/2015 [Academic Review of Permen KP No.2/Permen-KP/2015]. BPPFPIK Universitas Brawijaya, Malang (in Indonesian).

43. SUPRAPTI Y., DHUHA R.S., MUNIR M., 2017, Persepsi nelayan cantrang terhadap Peraturan Menteri Kelautan dan Perikanan Nomor 2 Tahun 2015 [Fisherman's perception on the Minister of Maritime and Fisheries Regulation No. 2 on 2015], in: Journal of Economic and Social of Fisheries and Marine, 5(1), p. 104-115 (in Indonesian).

44. SUWARSIH, 2013, Pengaruh lama penarikan pada pengoperasian alat tangkap cantrang terhadap hasil tangkapan ikan demersal di perairan Brondong [The effect of pullout period on cantrang to demersal fishes catches in Brondong], in: Jurnal Harpodon Borneo, 6(2), p. 143-151 (in Indonesian).

45. XUE G., 2003, China and International Fisheries Law and Policy, Martinus Nijhof Publisher, Cambridge.

46. YOUNG M.A., 2016, International Trade Law Compatibility of Market-Related Measures to Combat Illegal, Unreported and Unregulated (IUU) Fishing, in: Marine Policy, 69, p. 209-219. 